\title{
Preparation and Mechanical Properties of Cemented Uranium Tailing Backfill Based on Alkali-Activated Slag
}

\author{
Fulin Wang $\mathbb{D}^{\mathbb{D}}$, Guoliang Chen $\mathbb{D}$, Lu Ji, and Zhengping Yuan \\ School of Resource \& Environment and Safety Engineering, University of South China, Hengyang 421001, China \\ Correspondence should be addressed to Fulin Wang; 2513625891@qq.com
}

Received 25 December 2019; Revised 28 February 2020; Accepted 20 March 2020; Published 25 April 2020

Guest Editor: Qiusong Chen

Copyright (C) 2020 Fulin Wang et al. This is an open access article distributed under the Creative Commons Attribution License, which permits unrestricted use, distribution, and reproduction in any medium, provided the original work is properly cited.

\begin{abstract}
Backfilling disposal based on cement solidification is one of the ways to solve the environmental and safe problems of uranium tailing surface stacking. Alkali-activated slag, especially sodium silicate activated geopolymer, has become the preferred cementing material for the uranium tailing backfilling system because of its advantages of corrosion resistance and high strength. In this paper, uranium tailings and slag are taken as research objects, and the unconfined compressive strength (UCS) is taken as the main quality index. The preparation method of the cemented uranium tailing backfill based on alkali-activated slag was studied, hereinafter referred to as CUTB. The effects of additive amount, activator amount and activator modulus on the strength of CUTB were investigated. The results show that alkali-activated slag is an effective cementing material for the backfilling system of uranium tailing aggregate. The maximum UCS of $28 \mathrm{~d}$ age in the test groups is $16.45 \mathrm{MPa}$. Quicklime is an important additive for preparing CUTB. When the amount of quicklime is $0 \%$, the early and late strengths of the filling body cannot be measured or at a very low level. At the age of $7 \mathrm{~d}$, the order of each factor is additive amount $>$ activator modulus $>$ activator amount, but at the age of $28 \mathrm{~d}$, the order of each factor is additive amount $>$ activator amount $>$ activator modulus. The test results can provide a basis for choosing cementitious materials for backfilling disposal of uranium tailings.
\end{abstract}

\section{Introduction}

Surface stacking is one of the most important disposal methods of uranium tailings, in which radioactive and nonradioactive materials migrate and disperse under the action of weathering leaching, causing pollution to soil, water, and air. However, as a kind of long-lived, largevolume and low (or extremely low) level radioactive solid waste, uranium tailings cannot be completely treated in the way of high (or medium) level radioactive solid waste disposal [1-5]. In the field of filling mining, paste filling has the characteristics of "no precipitation, no bleeding, and no segregation" and can effectively control the diffusion of harmful components in filling materials in groundwater, which is consistent with the principle of cement solidification method in radioactive solid waste [6-9]. Therefore, relevant experts put forward a method of backfilling disposal of uranium tailings based on cement solidification, which can effectively avoid the environmental and safe problems of surface stacking of uranium tailings. In order to avoid the secondary pollution of groundwater caused by uranium tailings filling underground, it requires that the filling body has better mechanical strength, chemical stability, and leaching resistance [10-13].

For the filling body formed by uranium tailings aggregate and cement cementitious material, the leaching resistance is closely related to the structural stability of the filling body, and the mechanical strength is the macroscopic performance of the stability. The structural stability of filling body is also related to the hydration and hardening products of cementitious materials. The hydration process of cementitious materials is affected by many factors, such as the physical and chemical properties of filling materials. Uranium tailings are generally characterized by containing radionuclides, sulfuric acid and heavy metals, multiple types of tailings formation and wide distribution of particle size, etc., which inevitably affect the hydration reaction and strength formation of cementing materials, thus affecting the 
mechanical strength, chemical stability and leaching resistance of filling body.

Slag-based cementitious materials generally have the advantages of corrosion resistance and high post-strength and can also solve the problems of expansion, strength reduction, and even disintegration of high-sulfur tailing aggregate filling body [14-21]. Geopolymer cementitious materials have a "crystal-like" structure consisting of circular molecular chains, which can segment metal ions and other toxic substances into cavities and which is one of the effective methods for toxic and nuclear waste treatment [22-26]. Based on this, alkali-activated slag or slag polymer, as a substitute for traditional cementitious materials, can theoretically improve the structural stability of filling body and then improve its leaching resistance. However, there are few studies on the strength formation mechanism of cemented uranium tailing backfill based on alkali-activated slag in China and throughout the world, so it is necessary to carry out experimental research on this.

In this paper, uranium tailings were used as filling aggregate and alkali activated water-quenched slag powder as cementitious material. The corresponding filling slurry was prepared according to a certain cement-sand ratio and water-solid ratio. The rheological properties of the filling slurry were measured by the yield stress and the average viscosity. The mechanical strength of filling body was measured by UCS. The mechanical properties of the CUTB system and the influence of activator parameters on it were explored.

\section{Materials and Methods}

2.1. Test Materials. The test materials mainly include uranium tailings, water-quenched slag powder, quicklime powder, liquid sodium silicate, sodium hydroxide, and water (as shown in Figure 1).

Uranium tailings are taken from a uranium tailings reservoir in China, with water content of $10.91 \%$, density of $2.55 \mathrm{t} / \mathrm{m}^{3}$, and volume density of $1.375 \mathrm{t} / \mathrm{m}^{3}$. The main chemical composition of experimental materials is shown in Table 1 (by XRF of PANalytical Axios), and the pH of uranium tailings was 5.29 by referring to "Soil quality-de-

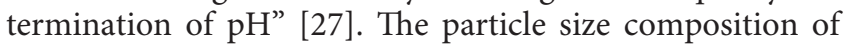
tailings obtained by the screening method is shown in Figure 2. The particle size ranged from 45 to 425 microns, and the median particle size was 208 microns. The average particle size was close to the median particle size. The results show that the coefficient of uniformity is 2.31 , the coefficient of curvature is 0.93 , the grain size distribution of tailings is discontinuous, the grain size distribution is not uniform, and the gradation is not good.

The slag powder was taken from a building material company in Hunan Province, China. It is white powder with a specific surface area of $445 \mathrm{~m}^{2} / \mathrm{kg}$, and the main chemical composition is shown in Table 1. According to "Granulated blast furnace slag used for cement production" and the works on slag eco-cement [28-30], the chemical modulus $K$ should not be less than 1.2 and the calculated $K=1.81>1.2$, so the slag is qualified. Because the alkali modulus of slag $M_{0}=0.85<1$ and the active coefficient $M_{\mathrm{a}}=0.48>0.30$, the slag is acid slag but belongs to high-activity slag. Quicklime purchased from the market is white powder with a specific surface area of $400 \mathrm{~m}^{2} / \mathrm{kg}$, and the content of $\mathrm{CaO}$ is $94.78 \%$. Sodium silicate was purchased from the market with a modulus of $2.80, \mathrm{Na}_{2} \mathrm{O}$ content of $10.27 \%$, and $\mathrm{SiO}_{2}$ content of $27.79 \%$. Sodium hydroxide is commercially available as a $99 \%$ pure industrial flake $\mathrm{NaOH}$ for adjusting the sodium silicate modulus. Water was directly supplied by urban tap water.

2.2. Test Scheme. In order to explore the effects of three factors, namely, the addition of quicklime (additive), $\mathrm{Na}_{2} \mathrm{O}$ alkali equivalent (activator addition), and activator modulus, on the rheological properties of filling slurry and strength formation of CUTB, the fixed water-solid ratio was 0.25 , the cement-sand ratio was $1: 4$, the mass ratio of quicklime to cementing material was $0 \%, 4 \%, 6 \%$, and $8 \%$, the mass ratio of $\mathrm{Na}_{2} \mathrm{O}$ alkali equivalent to cementing material was $0 \%, 4 \%$, $6 \%$, and $8 \%$, and the activator modulus was $0.8,1.0,1.2$, and 1.4, as shown in Table 2.

Test methods: as the particle size composition of uranium tailings is similar to that of construction sand, the preparation of filling slurry, the filling and curing of test mold, and the test of compressive strength shall refer to "Standard for test method of performance on building mortar" and the corresponding test method of tailing cemented backfill [31-34]. When the filling slurry preparation was completed, the yield stress and average viscosity of the slurry were obtained by testing the rheological parameters with MCR52 Modular Intelligent Advanced Rheometer. And, the prepared slurry was poured into rightprism molds of dimensions $70.7 \mathrm{~mm} \times 70.7 \mathrm{~mm} \times 70.7 \mathrm{~mm}$. The demoulded filling specimens were stored under laboratory conditions $\left(20 \pm 1^{\circ} \mathrm{C}\right.$, humidity $\left.\geq 95 \%\right)$ for curing. The specimens of the 11th group of CUTB after $14 \mathrm{~d}$ curing are shown in Figure 3. Three parallel specimens were prepared for each group, and the UCS tests were carried out on RMT$150 \mathrm{~B}$ tester at $7 \mathrm{~d}, 28 \mathrm{~d}$, and $56 \mathrm{~d}$, respectively. The test equipments are shown in Figure 4.

\section{Results and Discussion}

The rheological parameters of filling slurry under different excitation conditions and its UCS at different ages after filling body formation are shown in Table 3.

3.1. Stress-Strain Characteristics of CUTB. In order to study the general variation law of strength and deformation of CUTB during compression, the maximum compressive strength test data of $28 \mathrm{~d}$ age in group 9-16 are extracted and the stress-strain curve is plotted in Figure 5. It can be seen from Figure 5 that the CUTB shows a good bearing capacity after being compressed to a certain extent. The stress-strain curve can be divided into four stages: pore-crack compaction stage, elastic deformation to microelastic crack stable development stage, yield stage, and postfracture stage, which are basically similar to the characteristics of concrete. 


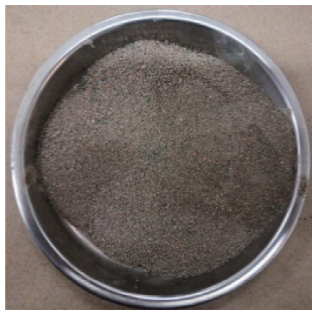

(a)

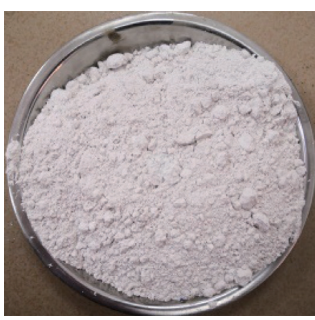

(b)

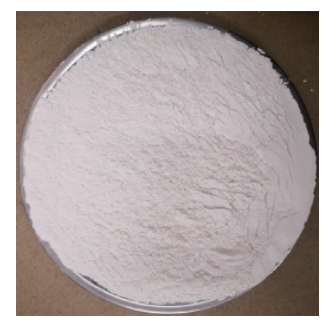

(c)

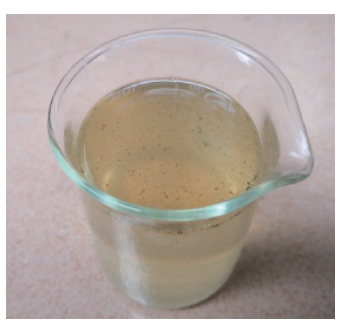

(d)

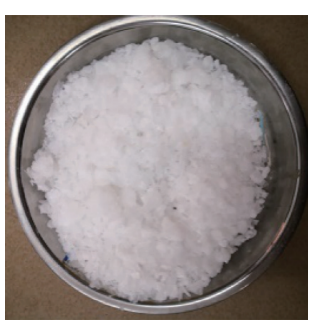

(e)

Figure 1: Main test materials. (a) Uranium tailings, (b) water-quenched slag powder, (c) quicklime powder, (d) liquid sodium silicate, and (e) sodium hydroxide.

TABle 1: Main chemical composition of test materials (\%).

\begin{tabular}{lcccccccccccc}
\hline & $\mathrm{SiO}_{2}$ & $\mathrm{Al}_{2} \mathrm{O}_{3}$ & $\mathrm{SO}_{3}$ & $\mathrm{~K}_{2} \mathrm{O}$ & $\mathrm{Fe}_{2} \mathrm{O}_{3}$ & $\mathrm{Na}_{2} \mathrm{O}$ & $\mathrm{CaO}$ & $\mathrm{TiO}_{2}$ & $\mathrm{P}_{2} \mathrm{O}_{5}$ & $\mathrm{MnO}$ & $\mathrm{MgO}$ & $\mathrm{U}$ \\
\hline Uranium tailings & 86.057 & 6.038 & 2.426 & 2.365 & 1.544 & 0.500 & 0.377 & 0.207 & 0.133 & - & 0.100 & 0.037 \\
Slag powder & 32.861 & 15.651 & 2.262 & 0.561 & 0.567 & 0.499 & 40.444 & 0.998 & 0.030 & 0.722 & 5.024 & - \\
Quicklime powder & 1.24 & 0.540 & - & 0.070 & 0.411 & 0.351 & 94.78 & 0.036 & 0.009 & 0.006 & 2.31 & - \\
\hline
\end{tabular}

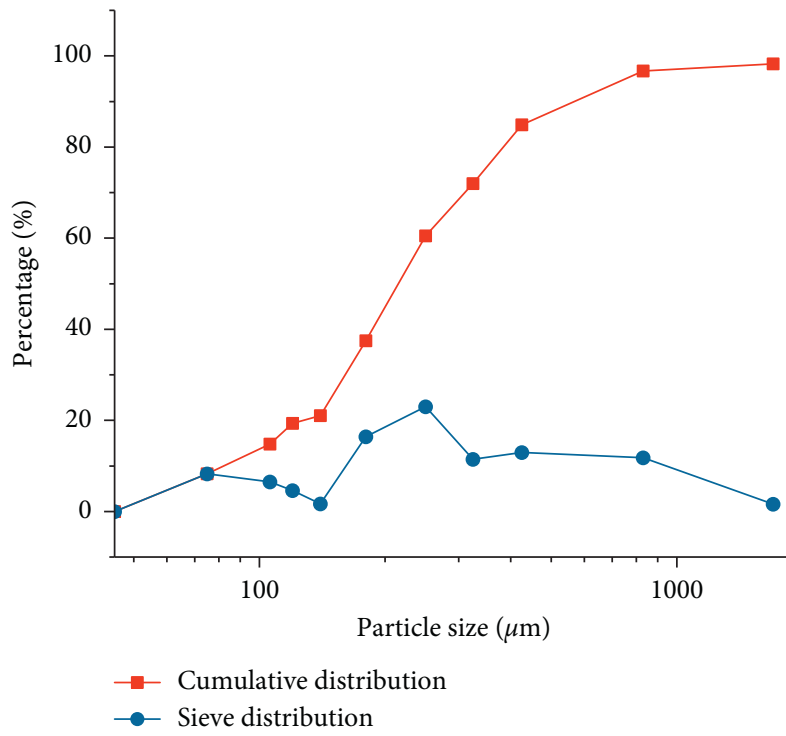

FIgURe 2: Particle size accumulation curve of uranium tailings.

3.1.1. Pore-Crack Compaction Stage. Because of discontinuous gradation of filling aggregate uranium tailings, uneven vibration during the pouring test, the structure of solidadsorbed water-air in filling body is unavoidable to be adjusted at the initial stage of loading. Pores, microfissures, and bubbles in the filling body are closing gradually, and the specimen shows significant axial compression and transverse deformation. This is quite different from that of hard and compact rock specimens. When the filling body is compressed to a certain extent, the load-bearing capacity of the specimen is improved and even sudden changes occur.

3.1.2. Elastic Deformation Stage. After the load-bearing capacity of the specimens is obviously increased, the stress increases linearly with the strain as the load increases, and the specimens are in the stage of elastic deformation to stable development of microelastic crack.
TABLE 2: Orthogonal experimental table of slurry ratio.

\begin{tabular}{lccc}
\hline Serial number & Quicklime (\%) & Alkali equivalent (\%) & Modulus \\
\hline 1 & 0 & 0 & 0.8 \\
2 & 0 & 4 & 1.0 \\
3 & 0 & 6 & 1.2 \\
4 & 0 & 8 & 1.4 \\
5 & 4 & 0 & 1.0 \\
6 & 4 & 4 & 0.8 \\
7 & 4 & 6 & 1.4 \\
8 & 4 & 8 & 1.2 \\
9 & 8 & 0 & 1.2 \\
10 & 8 & 4 & 1.4 \\
11 & 8 & 6 & 0.8 \\
12 & 8 & 8 & 1.0 \\
13 & 12 & 0 & 1.4 \\
14 & 12 & 4 & 1.2 \\
15 & 12 & 6 & 1.0 \\
16 & 12 & 8 & 0.8 \\
\hline
\end{tabular}

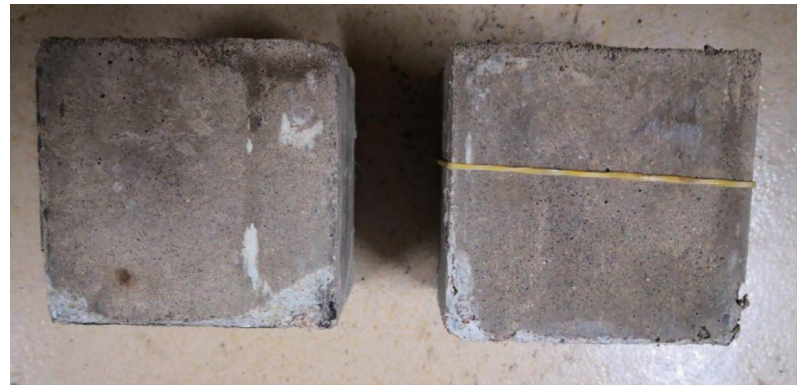

FIgURE 3: The 11th group of CUTB after $14 \mathrm{~d}$ curing.

3.1.3. Yield Stage. With the further increase of load, the microcracks in filling specimen gradually expand and change from elastic state to plastic state. The stress-strain curves of the specimens are concave and peak strength appears.

3.1.4. Failure Stage. After the specimen reaches its peak strength, the crack develops rapidly to form the 


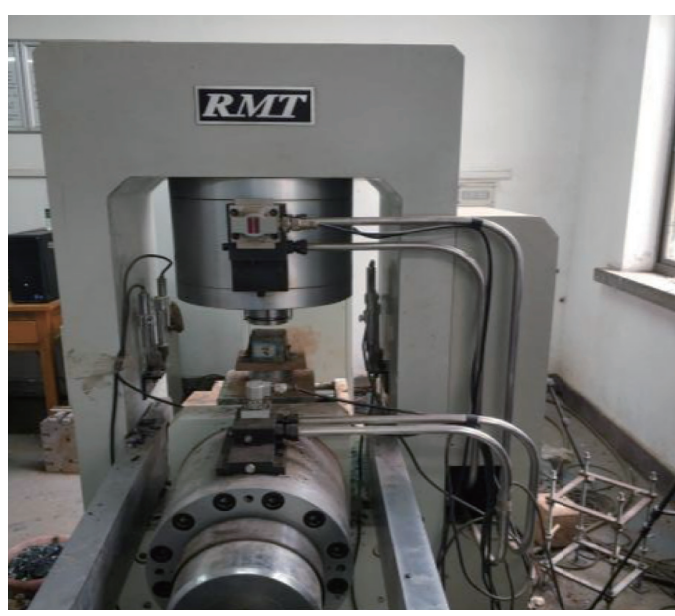

(a)

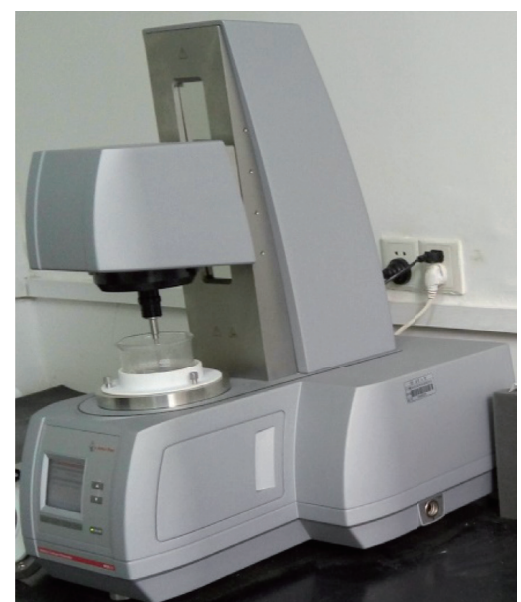

(b)

Figure 4: The test equipments. (a) RMT-150B. (b) MCR52.

TABLE 3: Test results of mechanical properties.

\begin{tabular}{|c|c|c|c|c|c|}
\hline \multirow{2}{*}{$\begin{array}{l}\text { Serial } \\
\text { number }\end{array}$} & \multicolumn{3}{|c|}{ UCS (MPa) } & \multicolumn{2}{|c|}{ Rheological parameter } \\
\hline & R7 & $\mathrm{R} 28$ & R56 & $\begin{array}{l}\text { Yield stress } \\
\quad(\mathrm{Pa})\end{array}$ & $\begin{array}{c}\text { Average viscosity } \\
\text { (Pa.s) }\end{array}$ \\
\hline 1 & - & - & - & 167.19 & 6.52 \\
\hline 2 & - & 0.06 & - & 288.98 & 8.62 \\
\hline 3 & - & 0.12 & - & 343.33 & 11.48 \\
\hline 4 & 0.20 & 0.23 & - & 264.75 & 8.17 \\
\hline 5 & 1.70 & 5.98 & 9.22 & 198.97 & 6.68 \\
\hline 6 & 4.90 & 8.76 & 10.66 & 297.85 & 12.17 \\
\hline 7 & - & 12.71 & 10.05 & 316.14 & 9.55 \\
\hline 8 & 0.72 & 16.45 & 6.05 & 494.81 & 14.28 \\
\hline 9 & 0.20 & 5.67 & 10.34 & 186.40 & 8.24 \\
\hline 10 & 3.90 & 6.23 & 9.86 & 413.88 & 12.08 \\
\hline 11 & 6.43 & 9.28 & 9.25 & 331.11 & 11.07 \\
\hline 12 & 7.55 & 11.08 & 11.47 & 221.60 & 5.96 \\
\hline 13 & 2.07 & 6.95 & 10.32 & 155.85 & 4.54 \\
\hline 14 & 5.15 & 8.05 & 7.87 & 302.32 & 8.57 \\
\hline 15 & 6.57 & 10.68 & 7.51 & 339.49 & 9.38 \\
\hline 16 & 5.20 & 9.77 & 10.27 & 250.97 & 6.87 \\
\hline
\end{tabular}

macroscopic fracture surface, resulting in irreversible plastic deformation, and the bearing capacity of the specimen decreases significantly. However, unlike hard and compact rock mass, the stress-strain curve of filling body after fracture is relatively smooth, which indicates that filling body still has better bearing capacity and residual strength.

3.2. Orthogonal Analysis of Strength Characteristics of CUTB. In order to study the influence of quicklime addition, $\mathrm{Na}_{2} \mathrm{O}$ alkali equivalent, and activator modulus on the strength formation of CUTB at fixed water-solid ratio and cement-sand ratio, the UCS of 16 groups of tests is analyzed by range analysis (as shown in Table 4 and Figure 6). The results show that the sensitivity of the influence on the strength of filling body is quicklime $>$ activator modulus $>$ alkali equivalent at $7 \mathrm{~d}$ age, and the optimal combination is A4B2C1. At $28 \mathrm{~d}$ age, the sensitivity of the

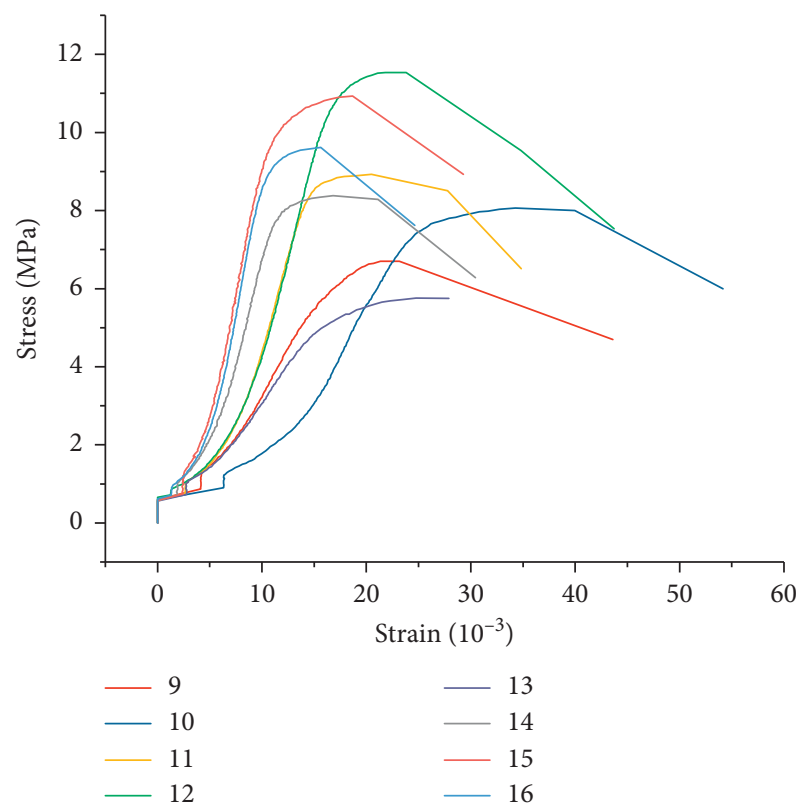

FIGURE 5: Stress-strain curve of CUTB.

influence on the strength of filling body is quicklime $>$ alkali equivalent $>$ activator modulus, and the optimal combination is $\mathrm{A} 2 \mathrm{~B} 4 \mathrm{C} 3$.

For the cemented backfill of uranium tailing aggregate, the sulfur content and weak acid properties are unfavorable factors for the preparation of CUTB. As the most commonly used neutralizing treatment materials of uranium tailings, quicklime can not only neutralize the acid uranium tailings but also have good coagulation promotion as air-hardening binding material. From the experimental results of $7 \mathrm{~d}$ age and $28 \mathrm{~d}$ age, it can be seen that quicklime has obvious effect on the strength of filling body. When quicklime is not added, the strength of filling body cannot be formed or it is very low. In this case, the optimal test was group 4 and the strength of $28 \mathrm{~d}$ age was only $0.23 \mathrm{MPa}$. This is similar to the conclusion of papers $[17,19]$. 
TABLE 4: Range analysis of UCS.

\begin{tabular}{|c|c|c|c|c|c|c|c|}
\hline \multirow{2}{*}{ Age } & \multirow{2}{*}{ Factor } & \multicolumn{4}{|c|}{ Average UCS (MPa) } & \multirow{2}{*}{ Range } & \multirow{2}{*}{ Optimal scheme } \\
\hline & & Level 1 & Level 2 & Level 3 & Level 4 & & \\
\hline \multirow{3}{*}{$7 \mathrm{~d}$} & $\mathrm{~A}$ & 0.050 & 1.830 & 4.520 & 4.748 & 4.698 & A4 \\
\hline & $\mathrm{B}$ & 0.992 & 3.488 & 3.250 & 3.417 & 2.496 & $\mathrm{~B} 2$ \\
\hline & $\mathrm{C}$ & 4.133 & 3.955 & 1.518 & 1.542 & 2.615 & $\mathrm{C} 1$ \\
\hline \multirow{3}{*}{$28 \mathrm{~d}$} & $\mathrm{~A}$ & 0.103 & 10.975 & 8.065 & 8.863 & 10.872 & A2 \\
\hline & $\mathrm{B}$ & 4.650 & 5.775 & 8.197 & 9.383 & 4.733 & B4 \\
\hline & $\mathrm{C}$ & 6.952 & 6.950 & 7.573 & 6.530 & 1.043 & $\mathrm{C} 3$ \\
\hline
\end{tabular}

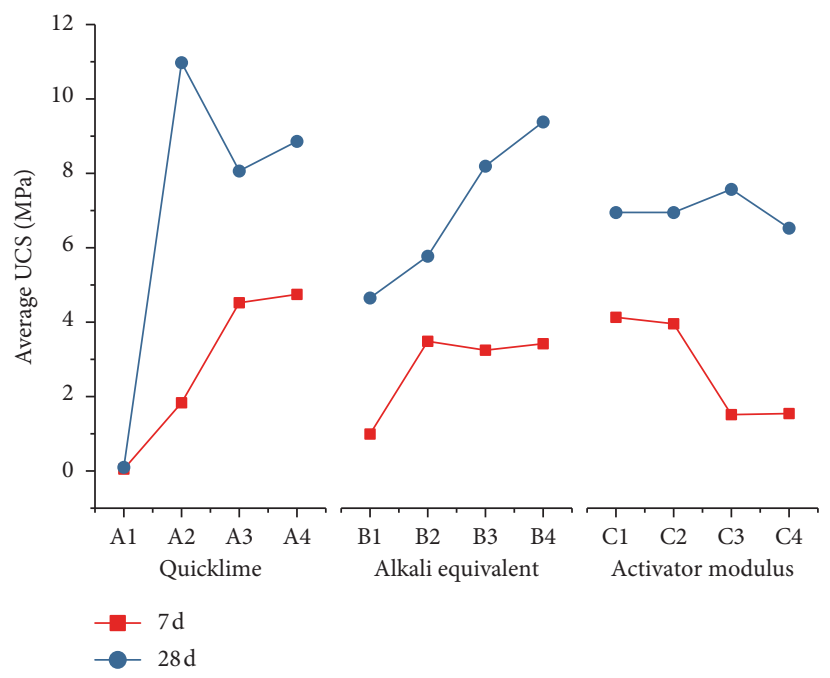

FIgURE 6: Trend chart of the average UCS VS factor level.

TABLE 5: Range analysis of rheological properties.

\begin{tabular}{|c|c|c|c|c|c|c|c|}
\hline \multirow{2}{*}{ Age } & \multirow{2}{*}{ Factor } & \multicolumn{4}{|c|}{ Average value } & \multirow{2}{*}{ Range } & \multirow{2}{*}{ Optimal scheme } \\
\hline & & Level 1 & Level 2 & Level 3 & Level 4 & & \\
\hline \multirow{3}{*}{ Yield stress } & $\mathrm{A}$ & 266.063 & 326.942 & 290.748 & 262.157 & 64.785 & A4 \\
\hline & B & 179.602 & 325.757 & 332.518 & 308.032 & 152.916 & $\mathrm{~B} 1$ \\
\hline & $\mathrm{C}$ & 261.780 & 262.260 & 334.215 & 287.655 & 72.435 & $\mathrm{C} 1$ \\
\hline \multirow{3}{*}{ Average viscosity } & $\mathrm{A}$ & 8.697 & 10.670 & 9.338 & 7.340 & 3.330 & $\mathrm{~A} 4$ \\
\hline & $\mathrm{B}$ & 6.495 & 10.360 & 10.370 & 8.820 & 3.875 & $\mathrm{~B} 1$ \\
\hline & $\mathrm{C}$ & 9.157 & 7.660 & 10.643 & 8.585 & 2.983 & $\mathrm{C} 2$ \\
\hline
\end{tabular}

When the activator modulus is low, the filling slurry is prone to rapid coagulation. Deb et al. [1] show that the strength of the backfill can reach $70 \%-80 \%$ of the final strength at $4 \mathrm{~h}$. In 16 groups of tests, the strength of $28 \mathrm{~d}$ age specimens is generally 1.15-3.52 times of that of $7 \mathrm{~d}$ age specimens, and only the 8th and 9th groups of specimens are more than 22 times, but the $28 \mathrm{~d}$ age strength of the 9th group of specimens was only $5.67 \mathrm{MPa}$, which was due to the fact that only quicklime was used as cementitious material, but no cementitious material was added, and the content of quicklime in group 8 was less and the activation modulus was relatively high, which was the reason for the low strength at $7 \mathrm{~d}$ age.

3.3. Orthogonal Analysis of Rheological Properties of Filling Slurry. In order to study the rheological properties of filling slurry under fixed water-solid ratio and cement-sand ratio, the yield stress and average viscosity of 16 groups of tests were analyzed by range analysis (as shown in Table 5 and Figure 7). The results show that the sensitivity to the yield stress of slurry is alkali equivalent $>$ activator modulus > quicklime, and the optimal combination is $\mathrm{A} 4 \mathrm{~B} 1 \mathrm{C} 1$ with the minimum yield stress. The sensitivity to the average viscosity of slurry is alkali equivalent $>$ quicklime $>$ activator modulus, and the optimum combination is A4B1C2 with the minimum average viscosity index.

Only from the point of view of rheological properties, yield stress and average viscosity increase first and then decrease with the addition of quicklime, $\mathrm{Na}_{2} \mathrm{O}$ alkali equivalent, and modulus of activator. The results can provide an optimum reference for industrial application of cemented uranium tailings backfill based on the alkali-activated slag system. 


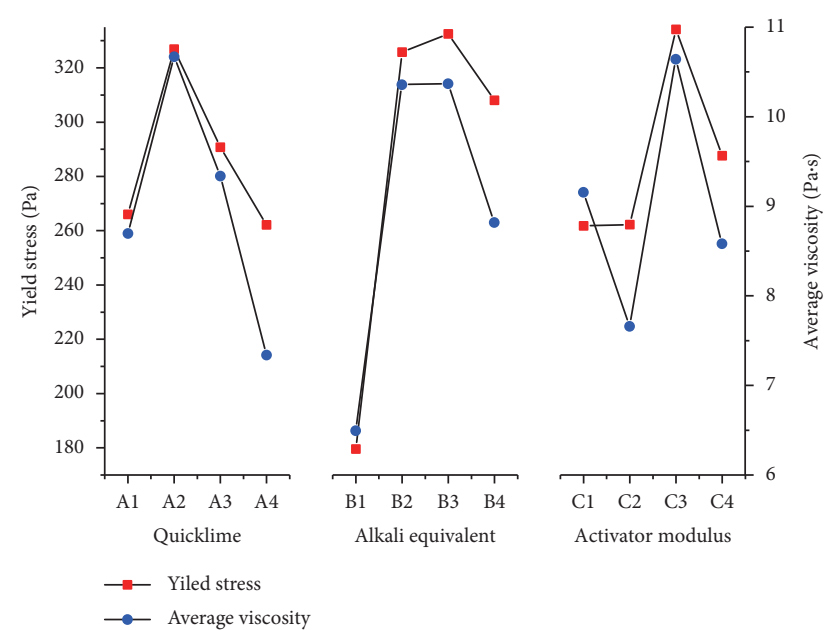

FiguRe 7: Trend chart of average yield stress and viscosity VS factor level.

\section{Conclusions}

Taking uranium tailings and slag as research objects, the preparation method of CUTB was studied by using the UCS quality index. The effects of additive amount, activator amount, and activator modulus on the strength of CUTB were investigated. The main conclusions are as follows:

(1) Alkali-activated slag is an effective cementing material for the uranium tailing aggregate filling system. The maximum UCS of $28 \mathrm{~d}$ age in the test groups is 16.45 MPa.

(2) Quicklime is an important additive for the preparation of CUTB. When the content of quicklime is $0 \%$, the early and late strengths of filling body cannot be measured or can be done at a very low level.

(3) The activator modulus has a significant effect on the early strength of filling body, while the dosage of the activator has a significant effect on the later strength. At $7 \mathrm{~d}$ age, the order of each factor is the dosage of additive $>$ the activator modulus $>$ the dosage of activator. At $28 \mathrm{~d}$ age, the order of each factor is the dosage of additive $>$ the dosage of activator $>$ the activator modulus.

The cemented uranium tailing backfill based on alkaliactivated slag is a new research content. This paper preliminarily verifies the feasibility of preparation of CUTB from the perspective of mechanical properties, but there are still several problems to be further explored in the future research:

(1) Under the influence of complex physical and chemical properties of uranium tailings, the hydration mechanism of alkali-activated slag cementitious material needs to be explored.

(2) The important goal of exploring CUTB is to solidify the uranium in uranium tailings, and its solidifying mechanism needs to be further explored.
(3) In order to give full play to the structural advantages of the geopolymer cementitious material solidified uranium, it is necessary to further explore the compounding test of the cementitious material admixture based on the concept of geopolymer.

\section{Data Availability}

All data are available within the article and can be obtained from the corresponding author upon request.

\section{Conflicts of Interest}

The authors declare that there are no conflicts of interest regarding the publication of this article.

\section{Acknowledgments}

This research was funded by the National Natural Science Foundation of China (51904154) and the research fund of Henan Key Laboratory for Green and Efficient Mining and Comprehensive Utilization of Mineral Resources (S201611). The authors gratefully acknowledge these generous supports.

\section{References}

[1] D. Deb, T. Sreenivas, G. K. Dey, and S. Panchal, "Paste backfill technology: essential characteristics and assessment of its application for mill rejects of uranium ores," Transactions of the Indian Institute of Metals, vol. 70, no. 2, pp. 487-495, 2017.

[2] H. A. Abdel Ghany, I. E. El Aassy, E. M. Ibrahim, and S. H. Gamil, "White sand potentially suppresses radon emission from uranium tailings," Radiation Physics and Chemistry, vol. 144, no. 3, pp. 100-105, 2018.

[3] S. Panchal, D. Deb, and T. Sreenivas, "Mill tailings based composites as paste backfill in mines of U-bearing dolomitic limestone ore," Journal of Rock Mechanics and Geotechnical Engineering, vol. 10, no. 2, pp. 310-322, 2018.

[4] A. Al-Hashimi, "Uranium tailings disposal: review of current technology," International Journal of Environmental Studies, vol. 42, no. 1, pp. 53-62, 1992.

[5] P. Waggitt, A Review of Worldwide Practices for Disposal of Uranium Mill Tailings, Australian Public Service, Australia, 1994.

[6] E. Yilmaz and M. Fall, Paste Tailings Management, Springer, Cham, Switzerland, 2017.

[7] A. X. Wu and H. J. Wang, Theory and Technology of Paste Filling in Metal Mines, Science Press, China, 2015.

[8] A. A. V. Cerbo, F. Ballesteros, T. C. Chen, and M.-C. Lu, "Solidification/stabilization of fly ash from city refuse incinerator facility and heavy metal sludge with cement additives," Environmental Science and Pollution Research, vol. 24, no. 2, pp. 1748-1756, 2017.

[9] D. L. Wang, Q. L. Zhang, Q. S. Chen, C. C. Qi, Y. Feng, and C. C. Xia, "Temperature variation characteristics in flocculation settlement of tailings and its mechanism," International Journal of Minerals, Metallurgy and Materials, vol. 28, no. 3, 2020.

[10] J. Kot'átková, J. Zatloukal, P. Reiterman, and K. Kolar, "Concrete and cement composites used for radioactive waste deposition," Journal of Environmental Radioactivity, vol. 178179, pp. 147-155, 2017. 
[11] Z. Z. Wang, "The practice and knowledge of uranium tailings disposal," Uranium Mining and Metallurgy, vol. 28, no. 1, pp. 22-25, 2009.

[12] G. Clausen and J. F. Archibald, "Uranium mill tailings as backfill in underground uranium mines," Mining Science and Technology, vol. 1, no. 1, pp. 69-75, 1983.

[13] B. M. Thomson, P. A. Longmire, and D. G. Brookins, "Geochemical constraints on underground disposal of uranium mill tailings," Applied Geochemistry, vol. 1, no. 3, pp. 335-343, 1986.

[14] M. Criado, S. A. Bernal, P. Garcia-Triñanes, and J. L. Provis, "Influence of slag composition on the stability of steel in alkali-activated cementitious materials," Journal of Materials Science, vol. 53, no. 7, pp. 5016-5035, 2018.

[15] Y. Feng, J. Kero, Q. X. Yang et al., "Mechanical activation of granulated copper slag and its influence on hydration heat and compressive strength of blended cement," Materials, vol. 12, no. 5, Article ID 12050772, 772 pages, 2019.

[16] A. Rustandi, F. W. Nawawi, Y. Pratesa, and A. Cahyadi, "Evaluation of the suitability of tin slag in cementitious materials: mechanical properties and Leaching behaviour," Materials Science and Engineering, vol. 299, no. 1 Article ID 012046, 2018.

[17] Y. Feng, Q. S. Chen, Y. L. Zhou et al., "Modification of glass structure via $\mathrm{CaO}$ addition in granulated copper slag to enhance its pozzolanic activity," Construction and Building Materials, vol. 240, Article ID 117970, 2020.

[18] F. Saly, L. P. Guo, R. Ma, and W. Sun, "Properties of steel slag and stainless steel slag as cement replacement materials: a comparative study," Journal of Wuhan University of Technology (Materials Science), vol. 33, no. 6, pp. 156-163, 2018.

[19] H. Z. Jiao, S. F. Wang, A. X. Wu, H. M. Shen, and J. D. Wang, "Cementitious property of $\mathrm{NaAlO}_{2}$-activated Ge slag as cement supplement," International Journal of Minerals, Metallurgy and Materials, vol. 26, no. 12, pp. 1594-1603, 2019.

[20] Y. He, Q. S. Chen, C. C. Qi, Q. L. Zhang, and C. C. Xiao, "Lithium slag and fly ash-based binder for cemented fine tailings backfill," Journal of Environmental Management, vol. 248, Article ID 109282, 2019.

[21] Y. Feng, Q. X. Yang, Q. S. Chen, and J. Kero, "Characterization and evaluation of the pozzolanic activity of granulated copper slag modified with $\mathrm{CaO}$," Journal of Cleaner Production, vol. 232, pp. 1112-1120, 2019.

[22] A. Hajimohammadi and J. S. J. van Deventer, "Characterisation of one-part geopolymer binders made from fly ash," Waste and Biomass Valorization, vol. 8, no. 1, pp. 225-233, 2017.

[23] K. C. Onyelowe, D. Bui Van, and M. Nguyen Van, "Swelling potential, shrinkage and durability of cemented and uncemented lateritic soils treated with CWC base geopolymer," International Journal of Geotechnical Engineering, vol. 9, pp. 1-16, 2018.

[24] A. Nikolov, I. Rostovsky, and H. Nugteren, "Geopolymer materials based on natural zeolite," Case Studies in Construction Materials, vol. 6, pp. 198-205, 2017.

[25] A. Mehta and R. Siddique, "Strength, permeability and microstructural characteristics of low-calcium fly ash based geopolymers," Construction and Building Materials, vol. 141, pp. 325-334, 2017.

[26] A. Bhutta, M. Farooq, C. Zanotti, and N. Banthia, "Pull-out behavior of different fibers in geopolymer mortars: effects of alkaline solution concentration and curing," Materials \& Structures, vol. 50, no. 1, p. 80, 2017.
[27] ISO, Soil Quality-Determination of pH, ISO10390: 2005, International Organization for Standardization, Geneva, Switzerland, 2005.

[28] Standardization Administration of China, Granulated Blast Furnace Slag Used for Cement Production, GB/T 203-2008, Standardization Administration of China, Beijing, China, 2008.

[29] H. S. Shi, Eco-cement and Waste Recycling Technology, Chemical Industry Press, Shanghai, China, 2005.

[30] Z. S. Lin, Slag Base Serise Eco-Cement, China Building Materials Press, Beijing, China, 2018.

[31] Chinese Construction Industry Standard, Standard for Test Method of Performance on Building Mortar, JGJ/T70-2009, Chinese Construction Industry Standard, Beijing, China, 2009.

[32] H. Z. Jiao, S. F. Wang, Y. X. Yang, and X. M. Chen, "Water recovery improvement by shearing of gravity-thickened tailings for cemented paste backfill," Journal of Cleaner Production, vol. 245, Article ID 118882, 2020.

[33] Z. Su, Q. S. Chen, Q. L. Zhang, and D. M. Zhang, "Recycling lead-zinc tailings for cemented paste backfill and stabilisation of excessive metal," Minerals, vol. 9, no. 11, Article ID 9110710. 710 pages, 2019.

[34] Q. S. Chen, Q. L. Zhang, C. C. Qi, A. Fourie, and C. C. Xiao, "Recycling phosphogypsum and construction demolition waste for cemented paste backfill and its environmental impact," Journal of Cleaner Production, vol. 186, pp. 418-429, 2018. 